\title{
FUNCTIONAL SIGNIFICANCE OF MRI DEFINED MESIAL TEMPORAL SCLEROSIS IN TEMPORAL LOBE EPILEPSY
}

\author{
ELZA MÁRCIA T. YACUBIAN*, ARTHUR CUKIERT ${ }^{*}$, PAULO CARRILHO*, CARMEN LISA JORGE*, \\ LIA ARNO FIORE*, CARLOS ALBERTO BUCHPIGUEL * *
}

SUMMARY.- The functional significance of MRI-defined mesial temporal sclerosis in temporal lobe epilepsy (TLE) is not completely established. In order to study the possible relationship between signals of mesial temporal sclerosis on MRI and interictal SPECT findings we selected 18 patients with complex partial seizures, unilateral temporal EEG focus and normal CT. The EEG focus was defined by the presence of interictal sharp waves and slow background on several scalp EEG obtained during many years of follow up in all patients and by ictal recordings with sphenoidal electrodes in 12 patients. Group I comprised patients $(n=11)$ in whom MRI showed mesial temporal sclerosis; group II patients $(n=7)$ had normal MRIs. All patients were submitted to interictal 99m-Tc HMPAO injections with concomitant EEG monitoring. Lateralized hypoperfusion ipsilateral to the EEG was found in 13 patients (72\%). In all Group II and in 6 Group I patients a temporal hypoperfusion was found. This SPECT study showed a higher positivity rate in patients with normal MRI than previously reported. On the other hand, in all these group II patients a neocortical origin of epileptic focus was suspected on clinical or electroencephalographic basis. Positive SPECT findings may be at least as prevalent in neocortical as in mesiolimbic epilepsy.

KEY WORDS: epilepsy, temporal lobe epilepsy, SPECT, MRI.

Significado funcional da esclerose mesial temporal definida por ressonância magnética em epilepsia do lobo temporal

RESUMO - O significado funcional dos sinais de esclerose mesial temporal observados em ressonância magnética ainda não está estabelecido. Para estudar as relações entre sinais de esclerose mesial temporal na ressonância magnética e alterações no SPECT intercrítico, foram selecionados 18 pacientes com epilepsia do lobo temporal cujo diagnóstico foi definido pela presença de descargas de ondas agudas e alentecimento da atividade de base em vários EEG obtidos durante vários anos de seguimento em todos os pacientes e por registros críticos com eletrodos esfenoidais em 12 pacientes. No grupo I foram incluídos pacientes $(n=11)$ com sinais de esclerose mesial temporal na ressonância magnética; no grupo II $(n=7)$, pacientes com ressonância normal. Em todos os casos a injeção do Tc 99 HMPAO foi realizada no período intercrítico com monitorização EEG. Foi observada hipoperfusão lateralizada ipsolateral ao foco definido pelo EEG em 13 pacientes (72\%). Todos os pacientes do grupo II e 6 pacientes do grupo I tiveram hipoperfusão temporal. Este estudo mostrou maior positividade de SPECT em pacientes com ressonância magnética normal do que tem sido referido na literatura. Como os pacientes do grupo II tinham sinais clínicos ou eletrencefalográficos sugestivos de origem neocortical de suas crises epilépticas, postulamos que hipoperfusão em estudos de SPECT pode ser demonstrada tanto em epilepsia temporal neocortical como mesiolímbica.

PALAVRAS-CHAVE: epilepsia, epilepsia temporal, SPECT, ressonância magnética.

Hospital das Clínicas, Faculdade de Medicina da Universidade de São Paulo (FMUSP): * Divisão de Neurologia; ** Instituto de Medicina Nuclear. Estudo parcialmente financiado por FAPESP - Fundação de Amparo à Pesquisa do Estado de São Paulo. Aceite: 4-março-1994.

Dra. Elza Márcia Targas Yacubian - Divisão de Neurologia, Hospital das Clínicas, FMUSP - Av. Dr. Eneas de Carvalho Aguiar 255, Instituto Central - sala 5011 A - 05403-000 São Paulo SP - Brasil. 
Patients with temporal lobe epilepsy (TLE) and normal computed tomography (CT) scans may have abnormalities demonstrated by magnetic resonance imaging (MRI) and single photon emission computed tomography (SPECT) using 99m-hexamethyl-propilene-amine-oxime (HMPAO).

MRI may exhibit a non-specific high signal intensity on T2 weighted images (T2WI) associated to a volumetric reduction in $\mathrm{T} 1$ weighted images (T1W) of a mesial temporal lobe structures. These abnormalities are concordant with the side of the actual focus in $18-62 \%$ of the cases ${ }^{6,11,13}$ and correlate to the pathological finding of mesial temporal sclerosis (MTS). MTS has been shown to represent at least $75 \%$ of the pathological findings in TLE. However, in some cases, the sides of histological and MRI abnormalities may not fully overlap or may be even distinct or dual ${ }^{11}$. Additionally, MTS has been demonstrated in patients with normal $\mathrm{MRI}^{11}$.

HMPAO-SPECT may exhibit focal hypofixation which reflects decreased regional cerebral blood flow. This perfusion disturbance is closely linked to the metabolic impairment demonstrated by positron emission tomography (PET) and both abnormalities correlate well with data from depth electrode recordings ${ }^{8}$. Some authors have shov29 in PET studies that focal hypometabolism is concordant with the abnormal MRI signal ${ }^{1,18}$. On the other hand, in some patients with MTS extensive hypometabolism in the lateral neocortex of the temporal lobe and even normal scans could be found ${ }^{17}$.

Patients with neocortical temporal lobe seizure origin may exhibit pronounced hypometabolism over the temporal lobe convexity 9 . Ryvlin et al. ${ }^{16}$ compared SPECT findings in temporal lobe epileptic patients whose MRI suggested MTS with patients with normal scans and concluded that lateralized hypoperfusion correlates well to the presence of MRI abnormalities. Patients with normal MRI had normal SPECT studies ${ }^{16}$.

SPECT findings in temporal lobe epileptic patients with or without MRI abnormalities were studied, and results are reported in this paper.

\section{METHODS}

Eighteen consecutive patients with refractory complex partial seizures (CPS) due to an unilateral temporal lobe focus who underwent video-EEG monitoring during evaluation at the University of São Paulo Medical School Hospital between May 1992 and June 1993 were studied.

The EEG focus was defined by the presence of interictal sharp waves and slow background on scalp EEG (3-12 recordings/patient; mean=6) obtained during many years of follow-up in all cases and by ictal recordings using scalp sphenoidal or zygomatic electrodes ( $1-12$ recordings/patient; mean $=3$ ) in 11 patients. The antiepileptic medication had been tappered off for the ictal recordings in the majority of these patients.

MR images were obtained in all patients on an 1.5 T System ( Signa, GE Medical System, Milwaukee). $\mathrm{T} 1$ and $\mathrm{T} 2 \mathrm{WI}$ were obtained on coronal, sagittal and axial plans with special emphasis over the temporal lobes.

HMPAO-SPECT scans were obtained using the Amersham International Kit (Ceretec) which was reconstituted with $1480 \mathrm{mBq}$ ( $40 \mathrm{mCi}$ ) of $99 \mathrm{~m}-\mathrm{Tc}$. The scanning dose was approximately $1110 \mathrm{mBq}(30 \mathrm{mCi})$ of $99 \mathrm{~m}$ Tc-HMPAO per patient. An interictal scan was performed in all patients; one of them had 2 scans with an 1-year interval. 18 channel EEG recordings were used to monitor brain activity during and at least 5 minutes after the radiopharmaceutical injection. The scanning procedure began 30-120 minutes after injection and was performed with a Siemens orbiter zlc 75 single-head rotating gamma camera, equipped with an ultra high resolution collimator and interfaced to the dedicated computer (Micro Delta). 64 planar images were obtained at $30 \mathrm{sec}$ per image on a $64 \times 64$ matrix producing approximately 70000 counts per planar image. Butterworth filtering (Nyquist frequency of 0.6 and order number of 10 ) was performed after reconstruction. Attenuation correction and pixel size determination were not routinely performed. Transaxial slices with a $6 \mathrm{~mm}$ thickness were reconstructed in the temporal plane. Coronal slices were reconstructed perpendicular to this plane. Sagittal images were also obtained. SPECT findings were blindly analyzed . 
Qualitative data were based on a standardized color scale matrix. Interhemispheric activity asymmetry was measured using symmetrical regions of interest placed over the temporal lobes on a $1.2 \mathrm{~cm}$ thick slice at the mid temporal level. Circles with at least $5 \times 5$ pixels of area were oriented symmetricaly in both temporal lobes through a specific protocol (Siemens). An asymmetry index was calculated by means of the following:

$$
\mathrm{AI}=(\mathrm{T}-\mathrm{t}) / \mathrm{t} \times 100
$$

where AI, asymmetry index; $\mathrm{T}$, temporal lobe with higher average counts or percentage activity; and $\mathrm{t}$, temporal lobe with lower average counts or percentage activity.

On the basis of previous regional Cerebral Blood Flow studies using the same 99m Tc HMPAO methodology, an $\mathrm{AI}$ below $10 \%$ was considered normal ${ }^{14,16}$.

According to the MRI results, patients were divided in two groups: 11 patients with MTS (Group I) on the side of the EEG focus and 7 patients (Group II) with normal MRI.

Differences between Group I and II patients with regard to sex, age and duration of epilepsy and the frequency of lateralized hypoperfusion were assessed by means of Fisher's exact probability test. The MannWhitney $\mathrm{U}$ test was used to compare the maximal AIs measured in each individual between the 2 groups.

\section{RESULTS}

The clinical and EEG findings are summarized in Table 1. Age ranged from 21 to 44 years (mean= 32) in Group I ( 7 males, 4 females) and from 16 to 62 (mean= 34) in Group II ( 5 males, 2 females). Duration of epilepsy ranged from 8 to 31 years $($ mean $=10$ ) in Group I and from $1-26$ years (mean $=13.8$ ) in Group II patients. There was no significant difference between the 2 groups with regard to sex, age and duration of epilepsy.

Table I. Clinical, EEG, CT and MRI findings.

\begin{tabular}{|c|c|c|c|c|c|c|c|c|c|}
\hline & $\begin{array}{l}\text { Patient } \\
n^{\circ}\end{array}$ & Sex & $\begin{array}{c}\text { Age } \\
\text { (years) }\end{array}$ & $\begin{array}{c}\text { Duration } \\
\text { of } \\
\text { epilepsy } \\
\text { (years) }\end{array}$ & $\begin{array}{c}\text { Site of } \\
\text { EEG } \\
\text { abnormalitie }\end{array}$ & $\begin{array}{c}\text { Number } \\
\text { of } \\
\text { interictal } \\
\text { EEGs }\end{array}$ & $\begin{array}{c}\text { Number } \\
\text { of } \\
\text { seizures } \\
\text { recorded }\end{array}$ & $\begin{array}{l}\text { CT } \\
\text { scan }\end{array}$ & $\begin{array}{c}\text { MRI } \\
\text { abnormalities }\end{array}$ \\
\hline \multirow{11}{*}{$\begin{array}{c}\text { Group I } \\
\text { High signal } \\
\text { intensity } \\
\text { on T2 WI }\end{array}$} & 1 & $\mathbf{M}$ & 22 & 8 & LT & 4 & - & $\mathrm{N}$ & LT \\
\hline & 2 & $\mathbf{M}$ & 41 & 30 & LT & 3 & - & $\mathbf{N}$ & LT \\
\hline & 3 & $\mathrm{~F}$ & 34 & 20 & RT & 6 & 1 & $\mathbf{N}$ & RT \\
\hline & 4 & $\mathbf{M}$ & 36 & 31 & $\mathrm{RT}$ & 10 & 2 & $\mathbf{N}$ & RT \\
\hline & 5 & $\mathbf{M}$ & 28 & 17 & RT & 9 & 3 & $\mathbf{N}$ & RT \\
\hline & 6 & $\mathbf{M}$ & 32 & 15 & RT & 5 & 2 & $\mathbf{N}$ & RT \\
\hline & 7 & $\mathbf{F}$ & 44 & 24 & RT & 3 & 2 & $\mathrm{~N}$ & RT \\
\hline & 8 & $\mathbf{F}$ & 38 & 13 & LT & 2 & 3 & $\mathbf{N}$ & LT \\
\hline & 9 & $\mathbf{M}$ & 26 & 21 & $\mathrm{RT}$ & 3 & - & $\mathbf{N}$ & RT \\
\hline & 10 & $\mathbf{M}$ & 21 & 13 & $\mathrm{RT}$ & 12 & 3 & $\mathbf{N}$ & RT \\
\hline & 11 & $F$ & 30 & 28 & LT & 3 & 3 & $\mathrm{~N}$ & LT \\
\hline \multirow{7}{*}{$\begin{array}{c}\text { Group II } \\
\text { Normal } \\
\text { MRI }\end{array}$} & 12 & $\mathbf{M}$ & 25 & 9 & RT & 5 & - & $\mathbf{N}$ & $\mathrm{N}$ \\
\hline & 13 & $\mathbf{M}$ & 41 & 15 & LT & 5 & - & $\mathrm{N}$ & $\mathbf{N}$ \\
\hline & 14 & $\mathbf{F}$ & 40 & 26 & RT & 4 & 1 & $\mathbf{N}$ & $\mathrm{N}$ \\
\hline & 15 & $M$ & 62 & 1 & LT & 4 & - & $\mathbf{N}$ & $\mathbf{N}$ \\
\hline & 16 & $\mathbf{M}$ & 33 & 20 & LT & 11 & 2 & $\mathbf{N}$ & $\mathrm{N}$ \\
\hline & 17 & $\mathbf{M}$ & 16 & 5 & LT & 10 & 12 & $\mathbf{N}$ & $\mathbf{N}$ \\
\hline & 18 & $\mathrm{~F}$ & 22 & 21 & RT & 11 & 2 & $\mathrm{~N}$ & $\mathbf{N}$ \\
\hline
\end{tabular}

F, female; M, male; LT, left temporal; RT, right temporal; N, normal. 
Table 2. Correlations between MRI and visual and quantitative SPECT analysis.

\begin{tabular}{|c|c|c|c|c|}
\hline & \multirow[b]{2}{*}{ Patient $\mathrm{n}^{\circ}$} & \multirow[b]{2}{*}{$\begin{array}{c}\text { Sitre of MRI } \\
\text { abnormalities }\end{array}$} & \multicolumn{2}{|c|}{ SPECT } \\
\hline & & & $\begin{array}{c}\text { Visual } \\
\text { analysis }\end{array}$ & $\begin{array}{c}\text { Maximal } \\
\text { temporal AI [\%] }\end{array}$ \\
\hline \multirow{12}{*}{$\begin{array}{c}\text { Group I } \\
\text { High signal } \\
\text { intensity } \\
\text { on T2 WI }\end{array}$} & 1 & LT & LT & 16 \\
\hline & 2 & LT & LT & 18 \\
\hline & 3 & RT & RT & 15 \\
\hline & 4 & $\mathrm{RT}$ & RT & 18 \\
\hline & 5 & RT & $\mathrm{N}$ & $\mathrm{N}$ \\
\hline & 6 & RT & $\mathrm{N}$ & $\mathrm{N}$ \\
\hline & 7 & RT & $\mathrm{N}$ & $\mathrm{N}$ \\
\hline & 8 & LT & $\mathrm{N}$ & $\mathrm{N}$ \\
\hline & 9 & $\mathrm{RT}$ & $\mathbf{N}$ & $\mathrm{N}$ \\
\hline & 10 & RT & $\mathrm{N}$ & $\mathrm{N}$ \\
\hline & & & RT & 30 \\
\hline & 11 & LT & LT & 16 \\
\hline \multirow{7}{*}{$\begin{array}{c}\text { Group II } \\
\text { Normal MRI }\end{array}$} & 12 & $\mathbf{N}$ & RT & 10 \\
\hline & 13 & $\mathrm{~N}$ & LT & 13 \\
\hline & 14 & $\mathrm{~N}$ & RT & 20 \\
\hline & 15 & $\mathrm{~N}$ & LT & 14 \\
\hline & 16 & $\mathrm{~N}$ & Post. LT & 13 \\
\hline & 17 & $\mathrm{~N}$ & Post. LT & 23 \\
\hline & 18 & $\mathrm{~N}$ & Post. RT & 13 \\
\hline
\end{tabular}

LT, left temporal; RT, right temporal; Post, posterior; N, normal

Asymmetry Index: $p=0.069$. Mann Whitney $U$ test.

Frequency of hypoperfusion: $\mathrm{p}=0.034$. Fisher's exact probability test.

All SPECT studies were performed interictally. The SPECT data are in Table 2. Asymmetry noted by visual analysis was evident in 13 patients ( 6 in Group I and all Group II cases). All of them showed temporal hypoperfusion. Semi quantitative studies were carried out for temporal lobe data obtained from these patients. All studies with hemispheric count differences higher than $10 \%$ were considered abnormal. Als ranged from $15-30 \%$ (mean $=18$ ) in Group I and from 10-23\% ( mean=15) in Group II patients with normal scans. Although this difference was not statistically significant ( $p>0.05)$, the Mann-Whitney test suggested a tendency for a positive association between MRI defined MTS and lower perfusion rates $(p=0.069)$. One patient from Group I had 2 SPECT studies, after being seizure free for at least 24 hours, with one year interval. One was normal and the other had the highest $\mathrm{AI}$ in this series (30\%).

There was a significant positive association between normal MRI and focal hypoperfusion ( $p=0.034$ ). On the other hand, while all Group I patients had clinical or EEG evidences of mesiobasal seizure origin, Group II patients had evidences of neocortical seizure origin. Case 12 had spikes projected over F8-T4 and not reflected at the sphenoidal electrodes. Case 13 had receptive aphasia preceding his CPS and an EEG focus over T5-P3; patient 17 had a T5-P3 focus; patients $14,15,16$ and 18 had a posterior temporal lobe focus and patients 14 , 16 and 18 also had a neocortical predominance of discharges during electrocorticography.

\section{COMMENTS}

Our results indicate that positive SPECT findings may be at least as prevalent in neocortical as in mesiolimbic epilepsy. $100 \%$ of the studies obtained in patients with normal MRI and clinical and/or EEG signs of neocortical seizure origin had temporal hypoperfusion on SPECT whereas only $50 \%$ of those with MRI defined MTS did so. 
Ryvlin et al. ${ }^{16}$ reported $18 \%$ of lateralized hypoperfusion in patients with normal MRI, a lower rate than previously reported $(40-67 \%)^{3,5,7,12}$. They postulated that this lower positive rate was related to the fact that only $\mathrm{AI}>10 \%$ was considered abnormal. Although we have used this same parameters which might represent restrictive criteria, we have found a high rate of temporal hypoperfusion in patients with probable neocortical epilepsy.

Rajek et al. ${ }^{9}$ demonstrated in a PET study of 25 patients with TLE a pronounced hypometabolism in the temporal convexity in cases with lateral temporal lobe seizure origin. On the other hand, they were not able to demonstrate a significant difference in glucose uptake in the lateral cortex or in the entire temporal lobe in patients with mesiobasal or neocortical seizure origin.

In patients with MRI defined MTS, Ryvlin et al. ${ }^{16}$ found $86 \%$ of temporal hypoperfusion, although rates as high as $91 \%$ have been reported ${ }^{2}$. We found $50 \%$ of abnormalities. When the maximal AI of Group I and Group II patients was compared, no significant difference was observed although there was some tendency for a positive association. This is also in disagreement with Ryvlin's results.

One group I patient had 2 SPECT studies with an 1-year interval. The first one was considered normal and the other showed an $\mathrm{AI}=30 \%$. Jibik et al. ${ }^{10}$ studied 13 cases of adults with partial epilepsy and reported a high reproducibility of regional abnormalities on SPECT. SPECT findings were reproducible in 8 out of 11 patients showing hypoperfusion in the first scan. However, in 3 of their patients different results were obtained by the time of the second SPECT scan.

The high frequency of abnormalities in SPECT scans in neocortical epilepsy with normal MRI disclosed by this study warrants further efforts to clarify the nature of the hypoperfusion found in such cases.

\section{REFERENCES}

1. Abou-Khalil BW, Siegel GJ, Sackellares JC, Gilman S, Hichwa R, Marshall R. Positron emission tomography studies of cerebral glucose metabolism in chronic partial epilepsy. Ann Neurol 1987, 22: 480-486.

2. Ancri D, Semah F, Adam C, Laplane D, Baulac M. Spect study of temporal lobe epilepsy patients with hippocampal atrophy demonstrated by MRI. (abstr). Epilepsia 1991, 32(Suppl 3): 98.

3. Andersen AR, Gram L, Kjaer L, Fuglsang-Frederiksen A, Herning M, Lassen NA, Dam M. SPECT in partial epilepsy: identifying side of the focus. Acta Neurol Scand 1988, 78 (Suppl 117): S90-94.

4. Berkovic SF, Newton MR, Rowe CC. Localization of epileptic foci using SPECT. In: Lüders HO (ed). Epilepsy surgery. New York: Raven Press, 1991, p 251-256.

5. Bluestone DL, Engelstad BL, Barbaro NM, Laxer KD. Tc-HMPAO SPECT imaging for intractable complex partial seizures of temporal lobe origin (abstr). Epilepsia 1989, 30: 690.

6. Convers P, Bierme T, Ryvlin P, Revol M, Fischer C, Froment JC, Maugeniere F. Brain magnetic resonance imagin (MRI) in drug-resistent partial epilepsy: a study of 100 patients with normal CT scans. Rev Neurol 1990, 146: 330-337.

7. Duval E, Coubes P, Badly-Moulinier M, Valmier J, Touchon J. Regional cerebral blood flow tomography by intravenous injection of Tc 99m HMPAO in partial epilepsy (abstr). Epilepsia 1989, 30: 718.

8. Engel J Jr, Kuhl DE, Phelps ME, Mazziotta JC. Interictal cerebral glucose metabolism in partial epilepsy and its relation to EEG changes. Ann Neurol 1982, 12: 510-517.

9. Hajek M, Antonini A, Leenders KL, Wieser HG. Mesiobasal versus lateral temporal lobe epilepsy: metabolic differences in the temporal lobe shown by interictal 18F-FDG positron emission tomography. Neurology 1993, 43:79-86.

10. Jibiki I, Kubota T, Fujimoto K, Yamaguchi N, Matsuda H, Tsuji S, Hisada K. High reproducibility of regional abnormalities on interictal 123 I-IMP SPECT brain scans in adults with partial epilepsy. Eur Arch Psychiatry Clin Neurosci 1990, 240:5-8.

11. Kuzniecky R, De La Sayette V, Ethier R, Melanson D, Andermann F, Bercovic S, Robitaile Y, Olivier A, Peters T, Frindel W. Magnetic resonance imaging in temporal lobe epilepsy: pathological correlations. Ann Neurol 1987, 22:341-347.

12. Lee BI, Markand ON, Wellman HN, Siddiqui AR, Mock B, Krepshaw J, Kung H. HIPDM single photon emission computed tomography brain imaging in partial onset secondarily generalized tonic-clonic seizures. Epilepsia 1987, 28:305-311. 
13. Mc Lachlan RS, Nicholson RL, Black NS, Carr T, Blume WT. Nuclear magnetic resonance imaging, a new approach to the investigation of refractory temporal lobe epilepsy. Epilepsia 1985, 26:555-562.

14. Moretti JL, Defer G, Cinotti L, Cesaro P, Degos JD, Vigneron N, Ducassou D, Holman BL. "Luxury perfusion"with $99 \mathrm{~m}$ Tc-HMPAO and 123 I-IMP SPECT imaging during the subacute phase of stroke. Eur J Nucl Med 1990, 16: 17-22.

15. Rowe CC, Berkovic SF, Austin MC, Saling M, Kalnins RM, McKay WJ, Bladin PF. Visual and quantitative analysis of interictal SPECT with technetium-99m-HMPAO in temporal lobe epilepsy. $J$ Nucl Med 1991, 32:1688-1694.

16. Ryvlin P, Garcia-Larrea L, Philippon B, Froment JC, Fischer C, Revol M, Maugui_re F. High signal intensity on T2-Weighted MRI correlates with hipoperfusion in temporal lobe epilepsy. Epilepsia 1992, 33:28-35.

17. Sackellares JC, Siegel GJ, Abou-Khalil BW, Hood TW, Gilman S, McKeever PE, Hichwa RD, Hutchins GD. Differences between lateral and mesial temporal metabolism interictally in epilepsy of mesial temporal origin. Neurology 1990, 40:1420-1426.

18. Theodore WH, Dorwart R, Holmes M, Porter RJ, Di Chiro G. Neuroimaging in refractory partial seizures: comparison of PET, CT, and MRI. Neurology 1986, 36:750-759. 